\title{
Anaerobic decomposition of a native and an exotic submersed macrophyte in two tropical reservoirs
}

\author{
Chiba de Castro, WA. ${ }^{a *}$, Cunha-Santino, MB. ${ }^{b}$ and Bianchini Junior, I. ${ }^{b}$ \\ ${ }^{a}$ Botanic Department, Federal University of São Carlos - UFSCar, Rod. Washington Luís, Km 235, SP 310, \\ CEP 13565-905, São Carlos, SP, Brazil \\ ${ }^{b}$ Hydrobiology Department, Federal University of São Carlos - UFSCar, Rod. Washington Luís, Km 235, SP 310, \\ CEP 13565-905, São Carlos, SP, Brazil \\ *e-mail: wagner.chiba@hotmail.com
}

Received June 29, 2012 - Accepted July 26, 2012 - Distributed May 31, 2013

(With 2 figures)

\begin{abstract}
Some aquatic plants have fast metabolism and growth, even at sub-optimal conditions, and become dominant in lentic environments such as large reservoirs, altering the nutrient cycle and impairing their environmental quality. There is great need in the knowledge impact processes of invasive species in aquatic environments, among the major, those related to the decomposition. This study evaluated the anaerobic decomposition of invasive submerged macrophytes Egeria densa Planch, native, and Hydrilla verticillata (L.f.) Royle, exotic in Porto Primavera and Jupiá reservoirs, Paraná basin. We evaluated the decay of organic matter, humification degree of the leached material, electrical conductivity and $\mathrm{pH}$ of the decomposition process. Mathematical models were utilised to describe the decomposition patterns over time. Both species showed the same heterogeneous pattern of decay of organic matter and carbon mineralisation. The models of carbon mineralisation, compared with the experimentally obtained data presented were adequate. Both species show no significant differences in the decomposition processes. Incubations of both species presented rapid $\mathrm{t}_{1 / 2}$ for POC mineralisation and low DOC mineralisation.
\end{abstract}

Keywords: mineralisation, mathematical models, lentic system, environmental impact.

\section{Decomposição anaeróbica de uma macrófita submersa nativa e de uma exótica em dois reservatórios tropicais}

\section{Resumo}

Algumas plantas aquáticas apresentam rápido metabolismo e desenvolvimento, mesmo em condições subótimas, tornando-se dominantes em ambientes lênticos, como em grandes reservatórios, alterando o ciclo de nutrientes e depreciando a qualidade ambiental. Existe grande necessidade do conhecimento das vias de impacto de espécies invasoras em ambientes aquáticos; dentre as principais, apontam-se as vias de impacto relacionadas à decomposição. Este estudo avaliou a decomposição anaeróbia das macrófitas submersas invasoras Egeria densa Planch., nativa, e da Hydrilla verticillata (Lf) Royle, exótica, nos Reservatórios de Porto Primavera e Jupiá, Bacia do Rio Paraná. Foram avaliados os seguintes aspectos: a decomposição da matéria orgânica, o grau de humificação do material lixiviado e a condutividade elétrica e o $\mathrm{pH}$ do processo de decomposição. Modelos matemáticos foram utilizados para descrever os padrões de decomposição ao longo do tempo. Ambas as espécies apresentaram o mesmo padrão heterogêneo de decomposição da matéria orgânica e mineralização do carbono. Os modelos de mineralização do carbono, em comparação com os dados obtidos experimentalmente, apresentaram boa convergência. As espécies não apresentaram diferenças significativas entre si nos processos de decomposição. As incubações das duas espécies apresentaram ť2 rápido para a mineralização do COP e baixo, para a mineralização do COD.

Palavras-chave: mineralização, modelos matemáticos, ambiente lêntico, impacto ambiental.

\section{Introduction}

A species is considered invasive when it acquires a competitive advantage following the disappearance of natural obstacles to their proliferation, enabling a rapid spread and conquest of new areas in which the population becomes dominant (Valery et al., 2008). Among aquatic plants, there are many species with a

high potential for invasion (Pieterse and Murphy, 1990). The aquatic plant community comprises a polyphyletic group of organisms, including angiosperms, ferns, mosses and some freshwater algae, occurring in seasonally or permanently flooded environments (Lacoul and Freedman, 2006; Chambers et al., 2008). Macrophytes also play a 
significant role in structuring aquatic environments, the nutrient cycle and biota maintenance (Wetzel, 2001). They spread, grow and reproduce rapidly, even in sub-optimal conditions, such as under intense competition (Spencer and Bowes, 1990), and have rapid metabolism and large biomass in eutrophic ecosystems (Pieterse and Murphy, 1990). Thus, macrophytes can be aggressive invaders, threatening the biodiversity and ecosystem processes in aquatic environments (Santamaria, 2002).

Among the main macrophyte species invading reservoirs, there are the submerged Egeria densa Planch. (native to Brazil) and Hydrilla verticillata (L.f.) Royle (exotic to Brazil). The genera Egeria and Hydrilla (Hydrocharitaceae) have been the focus of concern in Brazilian reservoirs due to their large biomass (Bianchini Júnior et al., 2010) leading to an increase in the amount of decomposed material, which may cause the decrease in oxygen concentration (Rose and Crumpton, 1996), alteration of redox potential (Van der Putten et al., 1997), increased rates of fouling (Rooth et al., 2003), changes in biogeochemical cycles, reduction of plant diversity (Meyerson et al., 2000), increased primary productivity (Jordan et al., 1990) and changes in trophic relationships (Batzer, 1998) available in these reservoirs.

The use of mathematical models to describe the exponential decomposition of particulate detritus (POM) is commonly observed, and in turn, linear models have been unsuccessful because the kinetic arguments that justify their use do not apply to vegetal decomposition (e.g. decomposition rates are constant, independent of the amount of debris). The adoption of the double exponential model for describing the decomposition process takes into account the heterogeneity of the substrate, i.e. admits distinctions concerning the chemical composition of detritus. Thus, the detritus is differentiated according to their potential degradation in this case having a labile and/or soluble fraction and another refractory fraction (Asaeda et al., 2000).

The potential effects of invasions by macrophytes are well described in other continents (Finlayson, 2005; Ali and Soltan, 2006; Mony et al., 2007), but there are no data about the potential effects of detritus contribution of invasive macrophytes in Neotropical reservoirs. Therefore, considering the need to understand the processes involving invasive macrophytes in tropical environments and the importance of the nutrient contribution of this group, the aim of this study was to describe the kinetic aspects of the anaerobic decomposition of the submersed aquatic plants Egeria densa and Hydrilla verticillata from the Jupiá and Porto Primavera reservoirs (Brazil), emphasizing the temporal decay of organic matter and carbon balance.

\section{Material and Methods}

\subsection{Study area}

The Parana basin's main rivers are the Paraná and Paraguay, occupying most of central southern South America (18 ${ }^{\circ}$ to $34^{\circ} \mathrm{S}$ and $45^{\circ}$ to $68^{\circ} \mathrm{O}$ ) (Agostinho et al., 2007).
The Porto Primavera hydroeletric reservoir (UHE Engenheiro Sergio Motta) is located on the Paraná River between the coordinates 53 to $52^{\circ} \mathrm{W}$ and 22 to $22^{\circ} 30^{\prime} \mathrm{S}$. The reservoir area is $2040 \mathrm{~km}^{2}$, with a volume of $15.7 \times 10^{6} \mathrm{~m}^{3}$, and a total length of the longitudinal axis of $250 \mathrm{~km}$ (Bianchini Junior et al., 2010). Reservoir Engenheiro Souza Dias (Jupiá hydroeletric) is located immediately upstream of the Porto Primavera hydroeletric reservoir. It has a flooded area of $330 \mathrm{~km}^{2}$, it is $5,495 \mathrm{~m}$ long and receives water from the Paraná, Tietê and Sucuriu rivers. The quality of water reaching the reservoir is heavily influenced by a variety of other reservoirs installed upstream, which retain suspended solids and nutrients (Roberto et al., 2009). So, they are characterised as mesotrophic reservoirs (sensu Vollenweider, 1968). According to Sousa et al. (2009), the first occurrences of Hydrilla verticillata in the Parana River downstream from this reservoir, dates back to 2005 and since then, this species has been found among the submersed macrophytes in the Paraná Basin. There are various problems with infestations of submerged aquatic plants such as Egeria densa, Egeria najas and Ceratophyllum demersum along the dam cascade of the Tiete River and in areas of the Paraná River with higher water transparency (Velini et al., 2005). Martins et al. (2009) conducted a survey of the infestation of macrophytes present in the tributaries and stretches of the Paraná River before the the Porto Primavera Reservoir was filled. H. verticillata, was not recorded in this survey and the species E. najas and E. densa were found with absolute frequency of $1.43 \%$ (sensu Mueller-Dombois and Ellemberg, 1974).

\subsection{Experimental design and sampling procedure}

Healthy samples of Egeria densa, Hydrilla verticillata and water were collected in the littoral region in the Jupiá and Porto Primavera reservoirs. Water samples were collected using a van Dorn bottle. In the laboratory, plant samples were washed and dried in an incubator at $40{ }^{\circ} \mathrm{C}$. Water samples were filtered in a cellulose ester filter $(\Phi=0.45 \mu \mathrm{m})$. Anaerobic incubations were carried out according to Bianchini Junior et al. (2002). Integral fragments of Hydrilla verticillata and Egeria densa macrophyte were incubated in 60 glass bottles $(500 \mathrm{~mL})$ at a ratio of $10 \mathrm{~g}(\mathrm{PS}) \mathrm{L}^{-1}$ in anaerobic conditions at the annual average temperature of the reservoirs $\left(25 \pm 1{ }^{\circ} \mathrm{C}\right)$. On the days when the samples were taken $(1,3,5,10,15$, 20, 30, 40, 50 and 65) three incubations (three replicates), of each species were fractionated into particulate organic matter (POM) and dissolved organic matter (DOM) by filtration in a glass membrane $(\Phi=1.2 \mu \mathrm{m})$. POM mass was determined gravimetrically (Wetzel and Likens, 1991) and converted into carbon-based (POC - particulate organic carbon).

To apply the mineralisation models, the percentage of POC in the macrophytes was estimated as $0.47 * \mathrm{POM}$ (Wetzel, 2001). The DOM was filtered and the concentrations of organic carbon (TOC), inorganic (TIC) and total carbon (TC) were measured with a carbon analyzer (Shimadzu, model TOC-5000A). The dynamics of the carbon fractions 
(POC, DOC and TIC) was assessed according to Wetzel (2001). Part of the dissolved fraction was used to determine the electrical conductivity values (potentiometric method, Digimed brand, model DM3), $\mathrm{pH}$ (potentiometric method, Qualxtron brand, model 8010) and the potential for humification according to Stevenson (1982) (reason E4 / E6) in a spectrophotometer (Ultrospec brand, model 2100 pro).

\subsection{Mathematical models}

The temporal variations of POC free ash were adjusted to a biphasic decay model (Equation 1; (Lousier and Parkinson, 1976; Jenkinson, 1977) using the iterative algorithm Levemberg-Marquardt (Press et al., 1993):

$P O C=\left(P_{L S} \times e^{-k_{T^{t}}}\right)+\left(P O C_{R} \times e^{-k_{R^{t}}}\right)$

where: $\mathrm{POC}_{\mathrm{LS}}=$ original content of labile organic carbon $(\%)$; $\mathrm{POC}_{\mathrm{R}}=$ initial content of organic carbon refractory $(\%) ; \mathrm{k}_{\mathrm{T}}=\mathrm{k}_{1}+\mathrm{k}_{2}$; the coefficient of overall mass loss ( $=$ coefficient of mineralisation labile $\left(\mathrm{k}_{1}\right)+$ coefficient of leached soluble $\left(\mathrm{k}_{2}\right)\left(\right.$ day $\left.\left.^{-1}\right)\right), \mathrm{k}_{\mathrm{R}}=$ coefficient of refractory mass loss $\left(\right.$ day $\left.^{-1}\right)$.

The formation and mineralisation of the COD were fitted according to Equation 2 (Cunha-Santino et al., 2010):

$\frac{d C_{D O C}}{d t}=k_{T}\left(\frac{k_{2}}{k_{T}} C_{P O C L S}\right)-k_{3} C_{D O C}$

where: $\mathrm{C}_{\mathrm{DOC}}=$ variation per unit time in the concentration of DOC and $\mathrm{k}_{\mathrm{T}}=$ leaching rate $\left(\mathrm{day}^{-1}\right) ; \mathrm{k}_{3}=$ mineralisation rate of DOC $\left(\right.$ day $\left.^{-1}\right)$;

The overall equation that includes the sum of all transformation processes of total carbon into TIC (total inorganic carbon) was elaborated according to CunhaSantino et al. (2010), described in Equation 3:

$\frac{d C_{T I C}}{d t}=k_{T} C_{P O C L}+k_{4} C_{P O C R}+k_{3} C_{D O C}$ where $\mathrm{C}_{\mathrm{TIC}}=$ variation per unit time in the concentration of TIC; $\mathrm{POC}_{\mathrm{L}}=$ change per unit time in the concentration of $\mathrm{POC}_{\mathrm{L}}$ (where $\mathrm{POC}_{\mathrm{L}}=$ labile particulate organic carbon $\left.=\mathrm{POC}_{\mathrm{LS}}-\mathrm{DOC}\right)$.

The half-life $\left(t_{1 / 2)}\right.$ of the decay of organic matter was calculated using Equation 4:

$\mathrm{t}^{1 / 2}=\ln (0.5) /-\mathrm{k}$

where $\mathrm{k}$ = decay coefficient of each type of plant fraction; to $\mathrm{POC}_{\mathrm{LS}}$, the coefficient used is $\mathrm{k}_{\mathrm{T}}$; to $\mathrm{POC}_{\mathrm{R}}$, the coefficient used is $\mathrm{k}_{\mathrm{R}}$.

\subsection{Statistical analysis}

A linear regression between the sum of the mineralisation model and the data of total inorganic carbon was performed, to assess whether mineralisation could be predicted by total inorganic carbon. To determine the significant differences between the anaerobic decomposition responses of the two species analysed, we used the ANCOVA statistical tests (Zar, 1999) in the computer program PAST, v.2.11 (Hammer et al., 2001), considering the sample covariance with the sampled days.

\section{Results}

\subsection{Anaerobic decay of organic matter}

The mathematical model parameters (Table 1) showed robust fittings for the mass loss process, where the coefficients of determination $\left(\mathrm{r}^{2}\right)$ obtained by kinetic fittings were 0.97 for $E$. dens $a$ and 0.96 for $H$. verticillata. The organic matter decay showed a biphasic pattern (Figure 1a and 1b) for both species. The $\mathrm{POC}_{\mathrm{LS}}$ percentage was $29.4 \%$ for $E$. densa and $23.2 \%$ for $H$. verticillata. The $\mathrm{POC}_{\mathrm{R}}$ percentage was $68.1 \%$ for $E$. densa and $76.7 \%$ for $H$. verticillata. The $t^{1} / 2$ regarding the decomposition process was 2 days $\left(\mathrm{POC}_{\mathrm{LS}}\right)$ and 88 days $\left(\mathrm{POC}_{\mathrm{R}}\right)$ for $E$. densa and 1 day $\left(\mathrm{COP}_{\mathrm{LS}}\right)$ and 94 days $\left(\mathrm{POC}_{\mathrm{R}}\right)$ for $H$. verticillata. The ANCOVA statistical test

Table 1. Parameters obtained from the mass model decay, where: $\mathrm{POC}_{\mathrm{LS}}=\mathrm{POC}$ labile/soluble fraction; $\mathrm{k}_{\mathrm{T}}=\mathrm{decay}$ coefficient (mineralisation coefficient of labile/soluble fraction + leachate coefficient); $\mathrm{POC}_{\mathrm{R}}=\mathrm{POC}_{\text {refractory fraction; }}$ $\mathrm{k}_{\mathrm{R}}=$ mineralisation coefficient of the refractory fraction, $\mathrm{DOC}=$ dissolved organic carbon; $\mathrm{k}_{3}=$ mineralisation coefficient of DOC, $\mathrm{t}_{1 / 2}=$ half-life, $\mathrm{E}=$ kinetic setting error and $\mathrm{r}^{2}=$ model adjustment coefficient.

\begin{tabular}{|c|c|c|c|c|c|c|}
\hline & $\begin{array}{c}\text { POC }_{L S} \\
(\%)\end{array}$ & $\mathbf{E}$ & $\begin{array}{c}\mathbf{k}_{\mathrm{T}} \\
\left(\mathrm{day}^{-1}\right)\end{array}$ & $\mathbf{E}$ & $\begin{array}{c}\mathbf{t}_{1 / 2} \\
(\text { day })\end{array}$ & \\
\hline E. densa & 29,4 & 3,6 & 0,356 & 0,101 & 2 & \\
\hline \multirow[t]{2}{*}{ H. verticillata } & 23,2 & 3,4 & 1,309 & 0,539 & 1 & \\
\hline & $\begin{array}{c}\text { POC }_{R} \\
(\%)\end{array}$ & $\mathbf{E}$ & $\begin{array}{c}\mathbf{k}_{\mathrm{R}} \\
\left(\text { day }^{1}\right)\end{array}$ & $\mathbf{E}$ & $\begin{array}{c}\mathbf{t}_{1 / 2} \\
(\text { day })\end{array}$ & $\mathbf{r}^{2}$ \\
\hline E. densa & 68,1 & 2,9 & 0,008 & 0,001 & 88 & 0,976 \\
\hline \multirow[t]{2}{*}{ H. verticillata } & 76,7 & 1,9 & 0,007 & 0,008 & 94 & 0,962 \\
\hline & $\begin{array}{c}\text { DOC } \\
(\%)\end{array}$ & $\mathbf{E}$ & $\begin{array}{c}\mathbf{k}_{3} \\
\left(\mathbf{d a y}^{-1}\right)\end{array}$ & $\mathbf{E}$ & $\mathbf{r}^{2}$ & \\
\hline E. densa & 13,9 & 1,1 & 0 & 0 & 0,79 & \\
\hline H. verticillata & 11,2 & 1,0 & 0 & 0 & 0,53 & \\
\hline
\end{tabular}



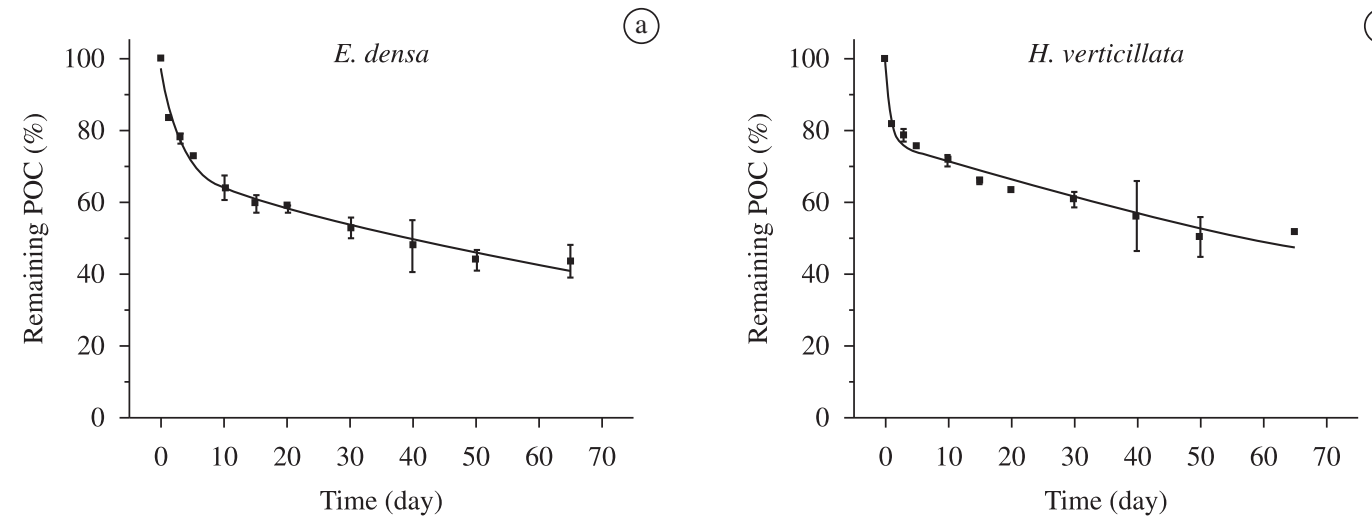

(c)
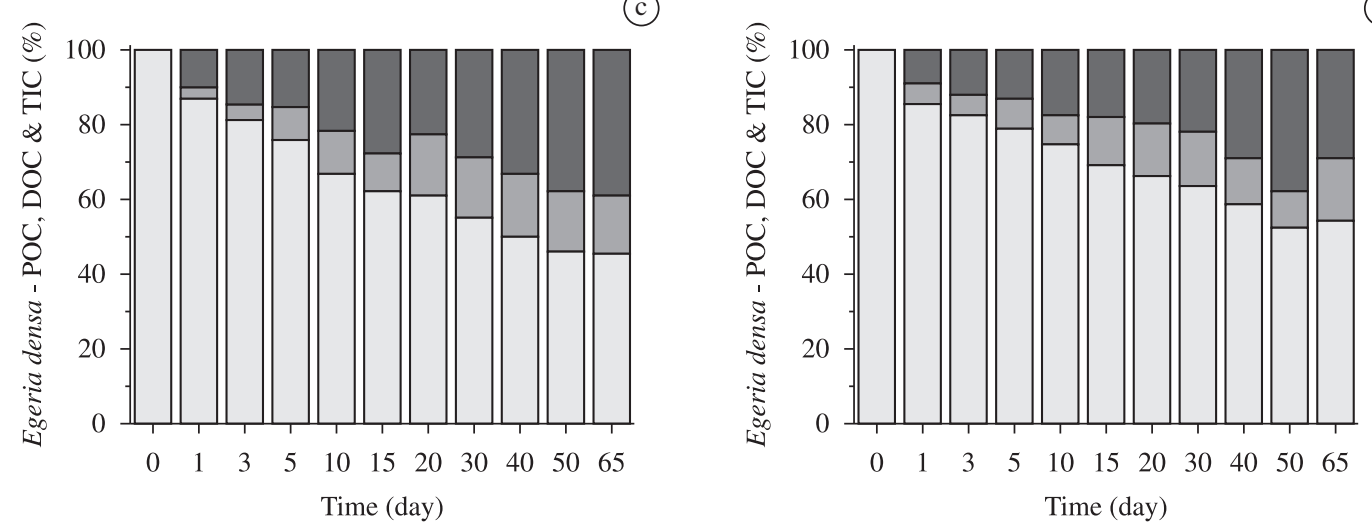

(e)
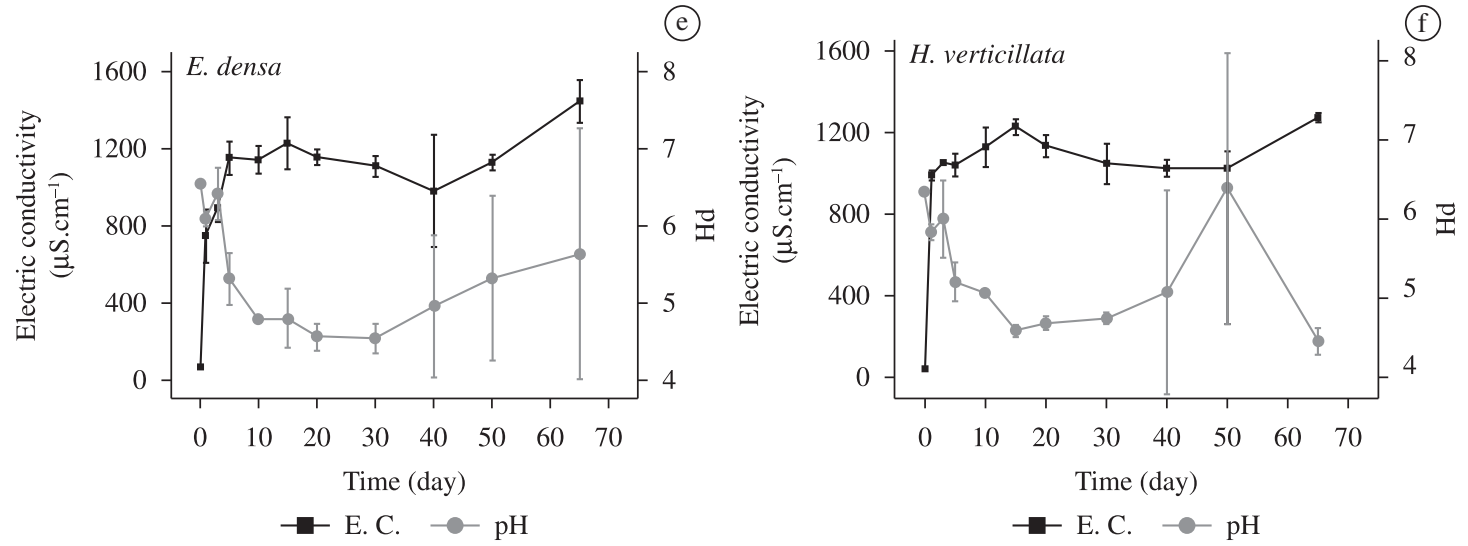

Figure 1. Kinetics of anaerobic decomposition of Egeria densa (a) and Hydrilla verticillata (b). Temporal variations of POC (white bars), DOC (gray bars) and TIC (black bars) from anaerobic decomposition of E. densa (c) and H. verticillata (d). Temporal variation of electric conductivity and $\mathrm{pH}$ of incubations of $E$. densa (e) and H. verticillata (f).

applied to the decay values found no significant differences in degradation kinetics of the two species $(p=0.4968)$.

The kinetic fittings of the mathematical model of the DOC formation and mineralisation (Equation 2) presented a coefficient of determination $\left(\mathrm{r}^{2}\right)$ by the kinetic adjustments of 0.79 for $E$. densa and 0.53 for $H$. verticillata (Table 1). The organic fraction of the dissolved carbon (DOC) is responsible for $13.9 \%$ of $E$. densa total organic carbon and $11.2 \%$ of $H$. verticillata total organic carbon. For both species, the DOC was not mineralised $\left(\mathrm{k}_{3}=0\right)$.
During the anaerobic decomposition of both species, there was a rapid fall in levels of POC (Figure 1c and 1d) according to the TIC + DOC generated on the first day of the experiment ( $14.7 \%$ to $\mathrm{H}$. verticillata and $13.1 \%$ to E. densa). After the decrease in POC, decay proceeded more slowly. Concerning the quantity of TIC, there was a tendency to increase its concentration throughout the process. At the end of the experiment, incubations of $H$. verticillata presented a higher proportion of POC (54.2\%) than E. densa (45.4\%). However, the POC decay process for the two species showed no significant 
differences according to ANCOVA ( $\mathrm{p}=0.4411)$, as well as TIC $(\mathrm{p}=0.4841)$ and DOC $(\mathrm{p}=0.5173)$.

The mineralisation model, which comprises the sum of the three pathways of mineralisation (Equation 3) was confronted by a linear regression with the data of total inorganic carbon, obtained experimentally. For $H$. Verticillata, the fitting $\left(\mathrm{r}^{2}\right)$ was 0.91 and deviation from the model was $10.4 \%$ for the experimental data. For E. densa, the fitting $\left(r^{2}\right)$ was 0.95 and deviation from the model was $2.3 \%$ for the experimental data.

\subsection{Electrical conductivity, $\mathrm{pH}$ and degree of humification of anaerobic incubation}

The incubations with $H$. verticillata showed electrical conductivity values slightly higher (993 and 1,274 $\left.\mu \mathrm{S} \mathrm{cm}^{-1}\right)$ than those with E. densa (750 and 1,230 $\mu \mathrm{S} \mathrm{cm}^{-1}$ ) (Figure 1e and 1f). The patterns of temporal changes were similar, and the electrical conductivity increased until the fifteenth day of the experiment $\left(1,228 \mu \mathrm{S} \mathrm{cm}^{-1}\right.$ for incubations with $H$. verticillata and $1,231 \mu \mathrm{S} \mathrm{cm} \mathrm{cm}^{-1}$ for incubations with E. densa). It then decreased until the fiftieth day for the incubations with $H$. verticillata $\left(1,023 \mu \mathrm{S} \mathrm{cm}^{-1)}\right.$ and the fortieth day for the $E$. densa incubations $\left(982 \mu \mathrm{S} \mathrm{cm}^{-1}\right)$. The values then increased from these days for both species.

The $\mathrm{pH}$ ranged between 4.43 and 6.39 in the $H$. verticillata incubations and between 4.54 and 6.54 in the E. densa incubations (Figure 1e and 1f). As for the temporal dynamics, the incubations with the two species were similar, having a sharp decrease in $\mathrm{pH}$ from the third day (6.00 for incubations with $H$. verticillata and 6.42 for incubations with $E$. densa) of the experiment and a marked increase from the thirtieth day (4.76 for $H$. verticillata incubations; 4.54 for $E$. densa incubations). Between the fiftieth day (6.39) and the sixty-fifth day (4.46), there was a marked decrease in the $\mathrm{pH}$ of the incubation with both species (from 6.39 to 4.46 in $H$. verticillata incubations; of 5.33 to 4.64 in E. densa.incubations). The ANCOVA did not demonstrate significant differences for both types of incubation for electrical conductivity $(p=0.2049)$ and $\mathrm{pH}(\mathrm{p}=0.9584)$.

It was observed that, for the incubations of the two species, the peak in absorbance occurred on day 5 (Figure 2). Once there was a decrease in absorbance, it remained relatively stable throughout the experiment. As for DOC, there was a rapid increase in concentration until the twentieth day. In the E. densa incubations, the DOC concentration remained constant, whereas in incubations with $H$. verticillata, there was a decrease until the fiftieth day $\left(432 \mathrm{mg} . \mathrm{L}^{-1}\right)$, when there was a peak in the sixty-fifth day $\left(744 \mathrm{mg} \cdot \mathrm{L}^{-1}\right)$. No differences were found between the DOC concentrations ( $p=0.4803)$ and the evaluated absorbance $(p=0.9579)$ for incubations of both species. The degree of humification of the two species, represented by E4/E6 (Figure 2c), ranged between 1.94 and 3.05 for
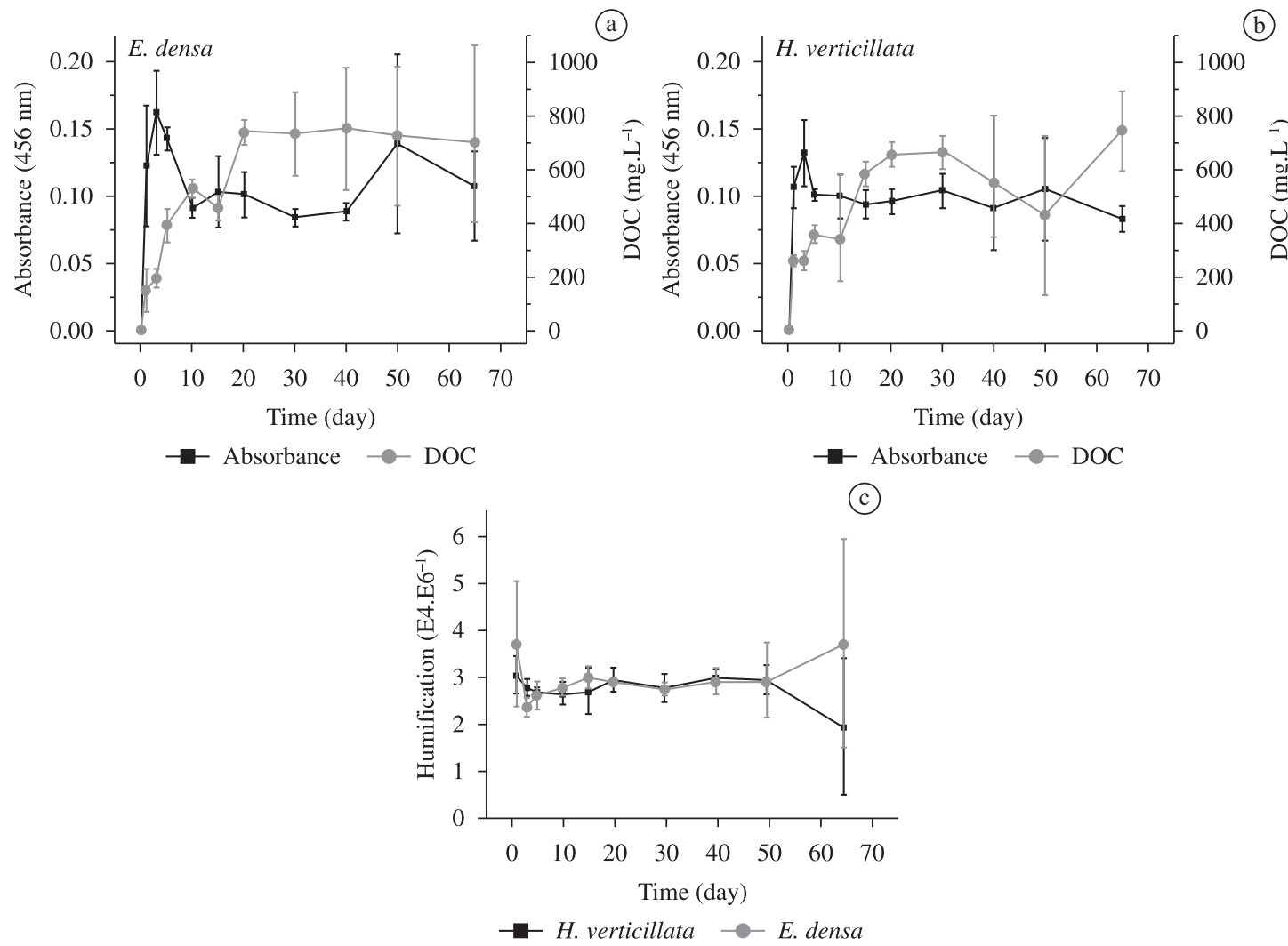

Figure 2. Temporal variation of DOC and optical density (465nm) (a and b) and E4/E6 values from anaerobic decomposition (c) of Egeria densa and Hydrilla verticillata. 
the $H$. verticillata incubations and 2.37 and 3.73 for the E. densa incubations. There was a decrease in E4/E6 until the third day for the $H$. verticillata incubations (from 3.72 to 2.37) and up to the tenth day for E. Densa incubations (3.05 to 2.66). Afterwards, there was a trend of stability for the values of this relationship. On the sixty-fifth day, there was a reduction in E4/E6 for the $E$. densa incubations (2.95 to 1.94 ) and a rise in the ratio in the $H$. verticillata incubations (from 2.94 to 3.73). However, according to ANCOVA, the E4/E6 showed no significant differences in incubations of the two species $(p=0.08668)$.

\section{Discussion}

For all the analysis of the anaerobic experiment carried out, there were no significant differences according to the ANCOVA test. This can be attributed to the species (both from the Hydrocharitaceae family) have a very similar composition. According to Sousa et al. (2009), who evaluated the occurrence of $H$. verticillata and $E$. najas in the Paraná basin, Brazil, they have many ecological and morphological similarities, and they probably compete in lakes and backwaters of the Paraná River. Bianchini Junior et al. (2010) evaluated the growth of $H$. verticillata in controlled conditions and found a potential for competition between this exotic species and native of the same habitat, such as E. densa. However, due to faster growth compared to native macrophytes, $H$. verticillata showed the highest competitive potential.

The kinetic fittings used to describe the mass loss (Equation 1) proved to be appropriate for the satisfactory parameterisation of anaerobic decomposition of the selected macrophytes; the mathematical model used considered the substrate as a heterogeneous resource (Bianchini Junior, 2003), consisting of labile/soluble fraction and refractory. The values of $\mathrm{POC}_{\mathrm{LS}}$ for the two species are close to values found for the submerged species $(34.1 \%)$ (Nunes et al., 2011). The coefficients of mass loss for both species were higher during the first stage of decomposition (first week). This pattern was due to a more rapid mass loss because of the leaching processes of protoplasmic fractions and subsequent dominance of the decomposition processes of the most recalcitrant fraction (Godshalk and Wetzel, 1978; Danell and Sjoberg, 1979; Ayyappan et al., 1986; Asaeda et al., 2000; Chimney and Pietro, 2006). The $t_{1 / 2}$ for the decay of organic matter from both species ( 88 days for $E$. densa and 94 days for $H$. verticillata) were low when compared with the values obtained for submerged species in various studies (Cunha and Bianchini Junior, 1998; Bianchini Junior, 1999, 2003; Asaeda et al., 2000; Nunes et al., 2011): an average of 156 days. However, these periods of half-life can not be accepted as the patterns of the two species because temperature acts as a fundamental role in determining the decay rate of organic matter (Barillier and Garnier, 1993). Thus, a different $t_{1 / 2}$ for the same species in distinct incubation temperatures might exist. Alterations in temperature affect both the bacterial community present in the substrate decomposition and the individual metabolism of decomposing microorganisms (Chin et al., 1999).

Mineralisation models obtained good convergence when confronted with the experimental values of TIC. The deviations, which were obtained (10.4\% for $H$. verticillata and $E$. densa $2.3 \%$ ), are mostly due to weak fittings for temporal variations of DOC (Equation 2). However, considering that the labile/soluble POC fraction corresponds to $29.4 \%$ for $E$. densa and $23.2 \%$ for $H$. verticillata, the deviations of the DOC model did not have a significant influence on the global carbon balance. According to Wetzel (1995), DOC in aquatic environments has great potential for incorporation by heterotrophic organisms. Thus, the DOC from the decomposing macrophyte process of leaching would be readily metabolised by bacteria due to its reactive nature (Faria and Esteves, 2001). However, for the two species studied, DOC presented great refractory potential, with null coefficients of mineralisation. In this context, the DOC in aquatic environments can predominantly (up to $60 \%$ ) consist of humic substances (HS) (Thurman, 1985). Considering the refractory nature of the DOC, it is assumed that the microorganisms involved in the degradation of HS are not metabolically adapted to the decomposition of the DOM in these experimental conditions (anaerobiosis, temperature and substrate type) (Cunha-Santino and Bianchini Junior, 2008). Another factor that contributes to the high refractory content found for the DOC is the concentration of FA (fluvic acid) and HA (humic acid). The FA consists of a less complex molecule than the HA and is more easily bioavaliable (Cunha-Santino and Bianchini Junior, 2004). In this study, the absorbance values of $465 \mathrm{~nm}$, which indicate the content of yellow substance related to humic acid, remained high throughout the experiment. These values, associated with high DOC concentrations observed during the experiment, may indicate the refractory DOC nature. For both species, the E4/E6 ratio was less than 5 , indicating the predominance of humic acids (HA) for fulvic acids (FA) (Osborne et al., 2007). This balance is frequently used in indicating the inverse relationship between the humification processes and the progressive increase in the condensation of organic matter (Tombácz, 1999). The decrease in the E4/E6 ratio is directly related to the increasing molecular weight and condensation of aromatic carbons (Saab and Martin-Neto, 2007). Thus, the E4/E6 observed suggests higher rates of HA on FA and would provide a DOC of refractory nature. Thus, the rapid decay of the POC in the early days of the experiment (Figure 1a and $1 \mathrm{~b}$ ) could be linked exclusively to the mineralisation of labile and not the soluble fraction, representing $15.5 \%$ of POC E. densa and $12 \%$ of $\mathrm{H}$. Verticillata, once the coefficient of mineralisation of DOC were practically zero for both species.

In the early days of anaerobic decomposition, there was a marked increase in the values of electrical conductivity for both species. This is due to the large amount of ions present in the leached material (Mun, 2000), this stage of decomposition (predominance of $\mathrm{POC}_{\mathrm{LS}}$ ) as well as the intense generation of bicarbonate. With each passing 
day, there was a gradual decrease in conductivity due to the mineralisation of leachate processes by using heterotrophic (Cunha-Santino et al., 2010) and assimilation of elements (biological immobilization). The $\mathrm{pH}$ values for the anaerobic decomposition presented the same order of magnitude and patterns of temporal variations obtained by Cunha-Santino et al. (2010). At first, there was a sharp decrease in $\mathrm{pH}$ due to the large number of intermediate compounds which are formed from the predominant process of decomposition of the $\mathrm{POC}_{\mathrm{LS}}$ causing acidification of the medium (e.g., formation of ammonium bicarbonate and acid organic). The subsequent increase in $\mathrm{pH}$ is related to denitrification reactions (Wetzel, 2001) and anaerobic ammonium oxidation (Mulder et al., 1995), predominantly during the processes of decomposition of the $\mathrm{COP}_{\mathrm{R}}$.

Regarding the $\mathrm{pH}$, the increase in values in the initial phase of mineralisation, as well as the increase observed for the electrical conductivity values are related to ion releases from the protoplasmic content of the cells, formation of humic compounds (Aguilar and Thibodeaux, 2005) and also by the solubility of nutrients in the culture medium. This process was also observed in decomposition studies performed with Egeria najas (Carvalho et al., 2005) and Typha domingensis (Cunha-Santino and Bianchini Junior, 2006). Despite the heterotrophic activity, which results in the decrease of conductivity by the consumption of the leachate (as observed in the conductivity standards anaerobic), there was no decrease in the values of conductivity and $\mathrm{pH}$ during the experiment. Cunha-Santino and Bianchini Junior (2006) detected the establishment of two buffer systems for $\mathrm{pH}$ due to humification and the carbonate system, which allows for $\mathrm{pH}$ values between 7.0 and 8,0 . In this experiment, the predominance of acidic conditions in the incubations (averages of 6.22 and 6.27) were probably due to a balance between system buffers and a constant supply of intermediate compounds during the entire process, which would have a tendency towards an acidification of the incubations (Weimer and Zeikus, 1978). High values of conductivity were also associated with the presence of these intermediate compounds probably originated from the refractory nature of DOC (Table 1), whose rates of mineralisation were low (practically zero) for both species, thus maintaining the high conductivity values during the process.

In the Porto Primavera and Jupiá reservoirs, there are problems related to the high occurrence of $H$. verticillata (Bianchini Junior et al., 2010) and E. densa (Velini et al., 2005), like losses in electric power generation and suppression of submerged native macrophytes occurrence. The results of this study indicate that the biomasses of these macrophytes would cause major changes in the nutrient cycle resulting from decomposition processes. As a result, there may be changes in the ecosystem in the short (e.g. increased availability of nutrients, reduced availability of dissolved oxygen) and long term (accumulation of particulate refractory material in the sediments, increased anaerobic heterotrophy).
Acknowledgements - The authors would like to thank the Conselho Nacional de Desenvolvimento Científico e Tecnológico (CNPq) (Process: proc. 302935/2007-0 and No. 131406/2010-8) and the Fundação de Amparo à Pesquisa do Estado de São Paulo (FAPESP) (Process: 2007/002683-7) for the scholarships and funding for this research project.

\section{References}

AGUILAR, L. and THIBODEAUX, LJ., 2005. Kinetics of peat soil dissolved organic carbon release from bed sediment to water. Part 1. Laboratory simulation. Chemosphere, vol. 58, p. 1309-1318. PMid:15686748. http://dx.doi.org/10.1016/j. chemosphere.2004.10.011

AGOSTINHO, AA., GOMES, LC. and PELICICE, FM., 2007. Ecologia e manejo de recurso pesqueiro em reservatórios do Brasil. Maringá: Eduem. 501 p.

ALI, MM. and SOLTAN, MA., 2006. Expansion of Myriophyllum spicatum (Eurasian water milfoil) into Lake Nasser, Egypt: invasive capacity and habitat stability. Aquatic Botany, vol. 84, p. 239-244. http://dx.doi.org/10.1016/j.aquabot.2005.11.002

ASAEDA, T., TRUNG, VK. and MANATUNGE, J., 2000. Modeling the effects of macrophyte growth decomposition on the nutrient budget in shallow lakes. Aquatic Botany, vol. 68, p. 217-237. http://dx.doi.org/10.1016/S0304-3770(00)00123-6

AYYAPPAN, S., OLÁH, J., RAGHAVAN, SL., SINHA, VRP. and PURUSHOTHAMAN, CS., 1986. Macrophyte decomposition in two tropical lakes. Archives of Hydrobiology, vol. 106, p. 219-231.

BARILLIER, A. and GARNIER, J., 1993. Influence of temperature and substrate concentration on bacterial growth yield in Seine River water Batch cultures. Applied and Environmental Microbiology, vol. 59, p. 1678-1682. PMid:8517757 PMCid:182138.

BATZER, DP., 1998. Trophic interactions among detritus, benthic midges, and predatory fish in a freshwater marsh. Ecology, vol. 79, p. 1688-1698. http://dx.doi.org/10.1890/00129658(1998)079[1688:TIADBM]2.0.CO;2

BIANCHINI JUNIOR, I., 2003. Modelos de crescimento e decomposição de macrófitas aquáticas. In: THOMAZ, SM., and BINI, LM. (Eds.). Ecologia e Manejo de Macrófitas Aquáticas. Maringá. vol. 1, p. 85-126.

-, 1999. Aspectos do processo de decomposição nos ecossistemas aquáticos continentais. In: POMPÊO, MLM. (Ed.). Perspectivas da Limnologia no Brasil. São Luís: União. p. 21-43.

BIANCHINI JUNIOR, I., CUNHA-SANTINO, MB., MILAN, JAM., RODRIGUES, CJ. and DIAS, JHP., 2010. Growth of Hydrilla verticillata (L.f.) Royle under controlled conditions. Hydrobiologia, vol. 644, p. 301-312. http://dx.doi.org/10.1007/ s10750-010-0191-1

BIANCHINI JUNIOR, I., PACOBAHYBA, LD. and CUNHASANTINO, MB., 2002. Aerobic and anaerobic decomposition of Montrichardia arborecens (L.) Schott. Acta Limnologica Brasiliensia, vol. 14, p. 27-34.

CARVALHO, FT., CAVENAGHI, AL. and BRONHARA, AA, 2003. Eficiência de fluridone no controle de plantas aquáticas submersas no reservatório de Jupiá. Planta Daninha, vol. 21, p. 69-77.

CHAMBERS, PA., LACOUL, P., MURPHY, KJ. and THOMAZ, SM., 2008. Global diversity of aquatic macrophytes in freshwater. Hydrobiologia, vol. 595, p. 9-26. http://dx.doi.org/10.1007/ s10750-007-9154-6 
CHIMNEY, MJ. and PIETRO, KC., 2006. Decomposition of macrophyte litter in a subtropical constructed wetland in South Florida, USA. Ecological Engineering, vol. 27, p. 301-321. http:// dx.doi.org/10.1016/j.ecoleng.2006.05.016

CHIN, JK., LUCKOW, T., STUBNER, S. and CONRAD, R., 1999. Structure and function of the ethanogenic archael community in stable cellulose-degrading enrichment cultures at two different temperatures $\left(15^{\circ} \mathrm{C}\right.$ and $\left.30^{\circ} \mathrm{C}\right)$. FEMS Microbial Ecology, vol. 30, p. 313-326.

CUNHA, MB., BIANCHINI JUNIOR, I., 1998. Mineralização aeróbia de Cabomba piauhyensis e Scirpus cubensis. Acta Limnologica Brasiliensia, vol. 10, p. 81-91.

CUNHA-SANTINO, MB. and BIANCHINI JUNIOR, I., 2008. Humic substances cycling in a tropical oxbow lagoon (São Paulo, Brazil). Organic Geochemistry, vol. 39, p. 157-166. http://dx.doi. org/10.1016/j.orggeochem.2007.12.001

-, 2006. The aerobic and anaerobic decomposition of Typha dominguensis Pers. Acta Limnologica Brasiliensia, vol. 18, p. 321-334.

-, 2004. Humic substances mineralisation: the variation of $\mathrm{pH}$, electrical conductivity and optical density. Acta Limnologica Brasiliensia, vol. 16, p. 63-75.

CUNHA-SANTINO, MB., BIANCHINI JUNIOR, I. and OKAWA, MH., 2010. The fate of Eichhornia azurea (Sw.) Kunth. detritus within a tropical reservoir. Acta Limnologica Brasiliensia, vol. 22, p. 109-121.

DANELL, K. and SJÖBERG, K., 1979. Decomposition of Carex and Equisetum in a northern Swedish lake: dry weight loss and colonization by macroinvertebrates. Journal of Ecology, vol. 67, p. 191-200. http://dx.doi.org/10.2307/2259344

FARIA, BM. and ESTEVES, FA., 2001. Dissolved organic carbon in two Brazilian coastal lagoons: sources and utilization for heterotrophic bacteria. Oecologia Brasiliensis, vol. 9, p. 5764. http://dx.doi.org/10.4257/oeco.2001.0901.05

FINLAYSON, CM., 2005. Plant ecology of Australia's tropical floodplain wetlands: a review. Annals of Botany, vol. 96, p. 541-555. PMid:16093268. http://dx.doi.org/10.1093/aob/mci209

GODSHALK, GL. and WETZEL, RG., 1978. Decomposition of aquatic angiosperms. II. Particulate components. Aquatic Botany, vol. 5, p. 301-327. http://dx.doi.org/10.1016/0304-3770(78)90074-8

HAMMER, Ø., HARPER, DAT. and RYAN, PD., 2001. PAST: Paleontological Statistics Software Package for Education and Data Analysis. Palaeontologia Electronica, vol. 4, no. 1, p. 1-9. Available from: <http://palaeo-electronica.org/2001_1/past/ issue1_01.htm>.

JENKINSON, DS., 1977. Studies on the decomposition of plant material in soil. V: The effect of plant cover and soil type on the loss of carbon from 14C-labelled ryegrass. European Journal of Soil Sciences, vol. 19, p. 25-39.

JORDAN, TE., WHIGHAM, DF. and CORRELL, DL., 1990. Effect of nutrients and litter manipulations on the narrow-leaved cattail, Typha angustifolia L. Aquatic Botany, vol. 36, p. 179-91. http://dx.doi.org/10.1016/0304-3770(90)90081-U

LACOUL, P. and FREEDMAN, B., 2006. Environmental influences on aquatic plants in freshwater ecosystems. Environmental Review, vol. 14, p. 89-136. http://dx.doi.org/10.1139/a06-001
LOUSIER, JD. and PARKINSON, D., 1976. Litter decomposition in a cool temperate deciduous forest. Canadian Journal of Botany, vol. 54, p. 419-436. http://dx.doi.org/10.1139/b76-041

MARTINS, D., PITELLI, RA., TOMAZELLA, MS., TANAKA, RH. and RODRIGUES, ACP., 2009. Levantamento da infestação de plantas aquáticas em Porto Primavera antes do encimento final do reservatório. Planta Daninha, vol. 27, p. 879-886.

MEYERSON, LA., SALTONSTALL, K., WINDHAM, L., KIVIAT, E. and FINDLAY, S., 2000. A comparison of Phragmites australis in freshwater and brackish marsh environments in North America. Wetlands Ecology and Management, vol. 8, p. 89-103. http://dx.doi.org/10.1023/A:1008432200133

MONY, C., KOSCHNICK, TJ., HALLER, WT. and MULLER, S., 2007. Competition between two invasive Hydrocharitaceae (Hydrilla verticillata L. f. and Egeria densa (Planch)) as influenced by sediment fertility and season. Aquatic Botany, vol. 86, p. 236242. http://dx.doi.org/10.1016/j.aquabot.2006.11.007

MUELLER-DOMBOIS, D. and ELLENBERG, H., 1974. Aims and methods of vegetation ecology. New York: John Wiley, Sons. 547 p.

MULDER, A., GRAAF, AA., VAN, DE., ROBERTSON, LA. and KUENEN, JG., 1995. Anaerobic ammonium oxidation discovered in a denitrifying fluidized bed reactor. FEMS Microbiology Ecology, vol. 16, p. 177-184. http://dx.doi.org/10.1111/j.1574-6941.1995. tb00281.x

MUN, HT., 2000. Mass loss and changes of mineral nutrients during decomposition of mushrooms, Russula alboaerolata and Lactarius violascens. Korean Journal of Biological Sciences, vol. 4, p. 51-55. http://dx.doi.org/10.1080/12265071.2000.9647523

NUNES, MF., CUNHA-SANTINO, MB. and BIANCHINI JUNIOR, I., 2011. Xylanase and cellulase activities during anaerobic decomposition of three aquatic macrophytes. Brazilian Journal of Microbiology, vol. 42, p. 75-83. http://dx.doi.org/10.1590/ S1517-83822011000100010

OSBORNE, TZ., INGLETT, PW. and REDDY, KR., 2007. The use of senescent plant biomass to investigate relationships between potential particulate and dissolved organic matter in a wetland ecosystem. Aquatic Botany, vol. 86, p. 53-61. http:// dx.doi.org/10.1016/j.aquabot.2006.09.002

PIETERSE, AH. and MURPHY, KJ., 1990. Aquatic Weeds. The Ecology and management of Nuisance Aquatic Vegetation. Oxford: Oxford Science Publications. 616 p.

PRESS, WH., TEUKOLSKY, SA., VETTERLING, WT. and FLANNERY, BP., 1993. Numerical Recipes in C: the art of scientific computing. Cambridge University Press, New York, 1256 p.

ROBERTO, MC., SANTANA, NF. and THOMAZ, SM., 2009. Limnology in the Upper Paraná River floodplain: large-scale spatial and temporal patterns, and the influence of reservoirs. Brazilian Journal of Biology, vol. 69, no. 2, p. 717-725. PMid:19738977. http://dx.doi.org/10.1590/S1519-69842009000300025

ROOTH, JE., STEVENSON, JC. and CORNWELL, JC. 2003. Increased sediment accretion rates following invasion by Phragmites australis: the role of litter. Estuaries, vol. 26, p. 475-483. http:// dx.doi.org/10.1007/BF02823724

ROSE, C. and CRUMPTON, WG., 1996. Effects of emergent macrophytes on dissolved oxygen dynamics in a prairie pothole wetland. Wetlands, vol. 16, p. 495-502. http://dx.doi.org/10.1007/ BF03161339 
SAAB, SC. and MARTIN-NETO, L., 2007. Anéis aromáticos condensados e relação E4/E6: estudo de ácidos húmicos de gleissolos por rmn de $13 \mathrm{c}$ no estado sólido utilizando a técnica CP/MAS desacoplamento defasado. Química Nova, vol. 30, p. 260-263. http://dx.doi.org/10.1590/S0100-40422007000200003

SANTAMARIA, L., 2002. Why are most aquatic plants widely distrited? Dispersal, clonal growth and small-scale heterogeneity in a stressful environment. Acta Oecologica, vol. 23, p. 137-154. http://dx.doi.org/10.1016/S1146-609X(02)01146-3

SOUSA, WTZ., SILVEIRA, MJ., MORMUL, RP., THOMAZ, SM. and MURPHY, KJ., 2009. Environmental predictors of the occurrence of exotic Hydrilla verticillata (L.f.) Royle and native Egeria najas Planch. in a sub-tropical river floodplain: the Upper River Paraná, Brazil. Hydrobiologia, vol. 632, p. 65-78. http:// dx.doi.org/10.1007/s10750-009-9828-3

SPENCER, W. and BOWES, G., 1990. Ecophysiology of the world's most troublesome aquatic weeds. In: PIETERSE, AH. and MURPHY, KJ. (Eds.). Aquatic weeds: The ecology and management of nuisance aquatic vegetation. New York: Oxford Science Publications. p. 40-51

STEVENSON, FJ., 1982. Humus chemistry: genesis, composition, reactions. New York: Wiley-Interscience. 512 p.

THURMAN, EM., 1985. Organic Geochemistry of Natural Waters. Netherlands: Nijhoff/Junk Po. 516 p.

TOMBÁCZ, E., 1999. Colloidal properties of humic acids and spontaneous changes of their colloidal state under variable solution conditions. Soil Science, vol. 164, p. 814-824. http:// dx.doi.org/10.1097/00010694-199911000-00005
VALERY, L., FRITZ, H., LEFEUVRE, JC. and SIMBERLOFF, D., 2008. In search of a real definition of the biological invasion phenomenon itself. Biological Invasions, vol. 10, p. 1345-1351. http://dx.doi.org/10.1007/s10530-007-9209-7

VAN DER PUTTEN, WH., PETERS, BAM. and VAN DEN BERG, RS., 1997. Effects of litter on substrate conditions and growth of emergent macrophytes. New Phytologist, vol. 135, p. 527-537. http://dx.doi.org/10.1046/j.1469-8137.1997.00678.x

VELINI, ED., CORREAA, MR., TANAKA, RH., BRAVIN, LF., ANTUNIASSI, UR. and CARVALHO, FT., 2005. Avaliação operacional do controle mecânico de plantas aquáticas imersas no reservatório de Jupiá. Planta daninha, vol. 23, p. 277-285.

VOLLENWEIDER, RA., 1968. Scientific fundamentals of the eutrophication of lake and flowing waters, with particular reference to nitrogen and phosphorus as factors in eutrophication. Technical Report. Paris: Water Management Research OECD. 159 p.

WEIMER, PJ. and ZEIKUS, JG., 1978. One carbon metabolism in methanogenic bacteria - cellular characterization and growth of Methanosarcina-barkeri. Archives of Microbiology, vol. 119, p. 49-57. PMid:718369. http://dx.doi.org/10.1007/BF00407927

WETZEL, RG., 1995. Death, detritus and energy flow in aquatic ecosystems. Freshwater Biology, vol. 33, p. 83-89. http://dx.doi. org/10.1111/j.1365-2427.1995.tb00388.x

-, 2001. Limnology: Lake and River ecosystems. 3rd ed. Philadelphia: Academic Press. 1006 p.

WETZEL, RG. and LIKENS, GE., 1991. Limnological Analyses. 2nd ed. Springer-Verlag. 444 p.

ZAR, JH., 1999. Biostatistical analysis. 4ed., New Jersey: Prentice-Hall Inc. 929 p. 